\title{
The KiK Case: A Critical Perspective from the South
}

\author{
Muhammad Azeem
}

\begin{abstract}
Labour in Global South countries often has meagre social security protections and almost no representation in domestic legislatures. To address this deficit, labour law's clear orientation towards "distributive justice" and emphasis on constitutionally protected freedom of association and collective bargaining rights have been core values for workers and labour movements in the South. Over the course of the last century, labour law has increasingly sought to assure "distributive justice" by departing from the confines of "corrective justice" and the slippery "ethical" basis of private law in both civil and common law systems. This chapter asks how both multinational corporations' (MNCs) recent turn toward the use of codes of conduct in regards to labour and working conditions (labour codes) and, correspondingly, activists' increasing reliance on the private law doctrines of tort and damages to resolve labour disputes, dilutes labour law's focus on "distributive justice." What problems and challenges do these shifts cause for labour law practice and theory? Taking the KiK case as an example, this chapter applies a critical legal perspective to address these questions.
\end{abstract}

Keywords Labor law · Private law - Labor codes of MNCs - Distributive justice · Labor litigation $\cdot$ Critical lawyering

\footnotetext{
M. Azeem ( $\bowtie)$

Shaikh Ahmad Hassan School of Law, D.H.A, Lahore, Pakistan

e-mail: muhammad.azeem@lums.edu.pk 


\section{Introduction}

In the context of global value and supply chains, ${ }^{1}$ workers in the Global South often struggle against the labour practices of both foreign investors and local manufacturers, where the latter are frequently dependent on the former for their foreign investment and capital. At times, labour unions in the Global North offer concrete transnational solidarity and unionisation support for workers and labour struggles in the South. Hence, both capital's overall structural logic (based on Northern investment and Southern dependency) and workers' collective struggles (based on international labour standards and transnational labour solidarity) dialectically shape labour conditions and labour law in the Global South.

Historically, both common and civil law systems considered the formation of labour associations and strikes to be modes of conspiring against business and property, and a violation of the "freedom of contract.", Yet, at the same time, private law's strictly moral and ethical basis, oriented toward "corrective justice," proved insufficient to adequately address the fundamental inequality between employers and employees. In response, labour law, with a strong orientation towards "distributive justice," emerged as an exception to and source of immunity and privilege for workers and organised labour from private law. At the national level, labour law took on a welfare orientation through social welfare legislation and state policy. At the international level, it developed through the International Labour Organization into a convention-based system of core standards tied to ratification, government responsibility, sanctions and enforcement mechanisms. Against this original labour law regime, the 1990s and the proliferation of neoliberal globalisation and rightsapproaches to address human suffering saw the International Monetary Fund, the World Bank and the Organisation for Economic Co-operation and Development push the ILO into the role of a social mediator through an evolving rights-based approach to labour law. ${ }^{3}$

\footnotetext{
${ }^{1}$ I use the terms global supply chains (GSCs), global value chains (GVCs) and transnational supply chains (TSCs) interchangeably to refer to MNCs' complex global production networks and chains, understood as a new form of global economic organisation, production and management. The ILO uses the term "GSC." See ILO, Follow-Up to the Resolution Concerning Decent Work in Global Supply Chains (General Discussion), (GB.328/INS/5/1 Geneva: ILO, 2016), whereas IGLP Law and Global Production Working Group uses the term GVC. See IGLP Law and Global Production Working Group, The Role of Law in Global Value Chains: A Research Manifesto, London Review of International Law (2016), for "TSCs" see United Nations Conference on Trade and Development (UNCTAD), Global Value Chains: Investment and Trade for Development, World Investment Report (New York and Geneva, 2013).

${ }^{2}$ Wedderburn (1987), p. 6.

${ }^{3}$ This understanding is based on debate between Phillip Alston and Brian Langille and its more theoretical explanation by Judy Fudge; see Alston (2004), p. 458; Langille (2005), pp. 409-437; Fudge (2007), pp. 29-66.
} 
This above shift in approach appeared in the ILO's Social Declaration of 1998 and, with some differences, in the EU's Charter of Fundamental Rights of $2000 .^{4}$ Declaration-based rather than entailing treaty ratification, a rights-based approach to labour regulation is promotional, meaning it aims to motivate stakeholders without binding sanctions, and shifts the regulatory burden away from governments onto corporations and consumers. Above all, it comprises "soft law" mechanisms as opposed to "hard," binding statutory labour law. One of its newest forms includes MNC's labour codes, corporate social responsibility policies, and the use of private tort law to seek damages for corporate violations of the standards they outline. ${ }^{6}$ As opposed to labour law's orientation towards "distributive justice," this rights-based approach to labour regulation is rooted in private law's emphasis on "corrective justice."

With this historical shift in mind, this chapter examines the KiK case as an example of the complex interactions and often diverging practices between international labour law standards and MNC's labour codes for manufacturers and/or contractors. ${ }^{7}$ It also explores how the KiK case exemplifies labour resistance and mobilisation through domestic and international labour litigation. In an attempt to unpack the challenging questions the resulting dynamics pose for labour law practice and theory, it uses the KiK case to test a theoretical proposition from the perspective of the South, namely that: International labour law must be assessed in regards to its (original) core objectives of redistribution, representation and power for labour in the South. Labour struggles and labour law must enhance Southern workers' power, representation and ensure redistribution. When discussing the litigation in the aftermath of the 2012 Ali Enterprises factory fire tragedy, I divide it into two cases: litigation in local courts in Pakistan, which I refer to as the Ali Enterprises case, and litigation by the victims of the factory fire against KiK in Germany, which I call the KiK case.

In the first part of the chapter, I offer a brief history of labour law's departure from private law in the early twentieth century, and its drift back in the 1990s under neoliberalism. In the second part, I discuss the nature and inclusion of labour law in MNCs' labour codes, demonstrating how these codes avoid questions of redistribution and representation and, hence, disempower both labour struggles and states in the Global South. In this phase of production and manufacturing in global supply chains, conventional national labour law no longer seems to offer adequate redress for labour, leading NGOs to increasingly resort to private tort and contract law to achieve "corrective justice" against the violation of these codes. But these

\footnotetext{
${ }^{4}$ Fudge (2007), pp. 29-66.

${ }^{5}$ Alston (2004), p. 457.

${ }^{6}$ I use the term "MNC labour codes" to refer to sets of labour standards adopted by MNCs in their global value chains (GVCs), including private compliance initiatives (PCIs) like voluntary codes of conduct as well as multi-stakeholder initiatives (MSIs) like social auditing and certificate initiatives. ${ }^{7}$ I use the term "contractors" for textile and garment manufacturers in the Global South, and the term "suppliers" for MNCs that place manufacturing orders from the Global North.
} 
approaches sidestep "redistributive justice," which has traditionally been at labour law's core. In the final section, I argue that a critical legal perspective is best suited to advance workers' interests in this situation.

\section{Labour Law as a Departure from Private Law}

In Western labour law debates, the "radical democratic tradition" emphasises the importance of statutory trade union recognition and rights to freedom of association, collective bargaining, and worker participation in corporate governance through a constitutional or public law lens. ${ }^{8}$ Since the 1990 s, however, labour law has been gradually turning away from such a public or constitutional law lens towards private (civil and common) law. This has also included a shift from binding conventionbased labour law to voluntary and promotional rights-based soft law for labour regulation. This relatively recent shift represents a reversal of labour law's emergence and trajectory since the early twentieth century, which was characterised by its departure from private law's emphasis on "corrective justice" towards and an explicit focus on "redistributive justice."

\subsection{Labour Law as a Departure from State and Courts}

With the emergence of capitalism in the West, classical liberal thought came to hold that political freedom brings economic freedom. Accordingly, private law (in both civil and common law systems) and state regulation were first limited to property and contracts. Despite political freedoms in Europe, workers were still subordinate to the market and capital, that is, political freedom did not lead to economic freedom (for workers). ${ }^{9}$

This was the context that compelled labour law's founding father Hugo Sinzheimer to constitutionalise labour-the economic sphere of life-as separate from the political sphere. With the creation of an "Economic Constitution" in the German Weimar Republic, he envisioned autonomously-created labour relations and norms between employers and trade unions, without the involvement of the state and courts. This process, he hoped, would give various sections of society like trade unions and employers' associations the power to spontaneously create law. ${ }^{10}$ Otto Kahn-Freund in England, like Sinzheimer, coined the idea of "collective laissezfaire," which entails employers bargaining with trade unions in spontaneous and non-institutionalised (i.e. non-legal) ways, and regulating conflict through statute. It

\footnotetext{
${ }^{8}$ For this debate, see Bogg (2017), pp. 7-37.

${ }^{9}$ Duke (2008), p. 346.

${ }^{10}$ Duke (2008), p. 346.
} 
was primarily a governmental policy that let trade unions and employers collectively bargain with each other-for instance, to overcome the parties' inequality in labour contracts and resolve the perpetual conflicts between employers and employeeswith limited oversight or regulation. With this concept, the law retreated from industrial relations and industrial relations retreated from the law. ${ }^{11}$ While Sinzheimer and Kahn-Freund were both against the state and law's interference in industrial relations, they differed on the question of the state's role. ${ }^{12}$

It is pertinent to mention here that basis of private law is "ethical" and "moral" and it is based on corrective justice, whereas one of the core values of labour law is distributive justice. Kahn-Freund believed that private law could not control collective action, but considered it capable of regulating organisations' conduct. ${ }^{13}$ Both, Sinzheimer and Kahn-Freund, believed, however, that civil law's freedom of contract - the idea that contracts are based on mutual agreement and free choice-was "pure fiction." On this basis, they argued that the market economy had no "natural law" of freedom of contract. ${ }^{14}$ In that sense labour law is constitutionally protected, but remains a matter of policy, depending on employer and employee negotiations.

\subsection{Labour Law as a Matter of Policy and Not "Ethics" and "Morality" of Private Law}

As we have discussed so far, labour law was a large departure from private law, as it moved workers' economic concerns away from the state. Do today's MNCs' labour codes and rights-based approaches signify labour law's return to private law, its ethical grounds, and their slippery interpretation by the courts? ${ }^{15}$ Here we must recall academics like Bill McCarthy, who were hesitant to bring ethics and rights into labour law. ${ }^{16}$ In the KiK case, the German retailer KiK claimed that it paid some compensation to victims on "ethical" grounds, but later refused to pay "legal" compensation. ${ }^{17} \mathrm{KiK}$ also made clear that it understood labour codes to be an ethical steering instrument rather than a "contract for the benefit of a third party" or a

\footnotetext{
${ }^{11}$ Dukes (2009), pp. 222-223. For a good summary of the development of collective bargaining in the UK before Kahn-Freund, see Lewis (1979), p. 613.

${ }^{12}$ Kahn-Freund wanted the government to intervene, Dukes (2009), p. 244.

${ }^{13}$ Kahn-Freund (1970), pp. 241-267.

${ }^{14}$ Coutu (2013), pp. 607-608.

${ }^{15}$ For recent discussion among Clare Mumme, William Kalre Roberts, and Mathew Dimick, see Mumme (2019).

${ }^{16}$ McCarthy (1964), pp. 1-6.

${ }^{17}$ Letter and correspondence between KiK and the Pakistan Institute of Labour Education and Research (PILER), on file with the author.
} 
"contract with protective effect to the benefit of a third party." 18 The Dortmund Regional Court that heard the case sided with the company, holding that "the code of conduct was addressed exclusively to the contractual partner of the defendant - in this case $\mathrm{KiK}$ - and that it urged the latter to maintain certain minimum ethical, social, and labour standards." 19 The court clearly said: "It cannot be inferred from the document that the employees of the defendant should be entitled to direct claims against the defendant as a result of the defendant's code of conduct."20

We can only comprehend this emphasis on labour codes as having an ethical bearing within the overall contemporary theoretical environment of labour law ideology. A relatively short time after labour law departed from private law, voices began circulating in the West warning of the "death of labour law" and the "crisis of labour law" in the late 1980s. ${ }^{21}$ Under neoliberalism, following the IMF and World Bank's lead in advocating for "flexibility of labour" and avoiding rigid social welfare legislation, the ILO came to act as "a social mediator in the process of globalization," 22 prompting the Declaration on Fundamental Principles and Rights at Work (1998), later known as the Social Declaration. ${ }^{23}$ This transformed a legal matter of substantive distribution into a moral one, including words like "human dignity" and placing it on a new symbolic ideological plane. ${ }^{24}$

In the past, nationally, labour law with a public and constitutional law lens viewed unfair labour practices as an administrative wrong. Internationally, labour law was convention-based and binding upon ratification by the ILO member countries. In the years following the rise of neoliberalism, labour law has slowly been moving towards a rights-based approach, with private law remedies based on corrective justice. Most labour law scholars agree that a public or constitutional labour law lens can better assure labour interests. However, few favour the rights-based approach. Allan Bogg, for instance, wants private law and labour law to work together. For him, treating unfair labour practices as administrative wrongs is limited, and should be reshaped by developing remedial principles within private law and by developing substantive doctrines. ${ }^{25}$ Similarly, Hugh Collins is fully convinced that labour law cases based on fundamental rights, not welfare or social justice, are weak. ${ }^{26} \mathrm{He}$ argues that labour rights are less compelling than human rights because they cannot

\footnotetext{
${ }^{18}$ Jabir and Others v. KiK Textilien und Non-Food GmbH, Case No. 7 O 95/15 (hereinafter KiK case) at 5 .

${ }^{19} \mathrm{KiK}$ case at 10.

${ }^{20} \mathrm{KiK}$ case at 10.

${ }^{21}$ Ewing (1988), p. 293. See also Bercusson and Estlund (2006), pp. 1-6. For redefining the discipline of labour law from a gender perspective, see Conaghan (2005).

${ }^{22}$ Fudge (2007), p. 39.

${ }^{23}$ ILO Declaration on Fundamental Principles and Rights at Work, www.ilo.org/declaration/lang\% 2D\%2Den/index.htm (last accessed 10 December 2019).

${ }^{24}$ Santos (2002), p. 483.

${ }^{25}$ Bogg (2017), pp. 7-37.

${ }^{26}$ Collins (2011), p. 140.
} 
be categorised as universal. While fundamental rights are timeless, labour rights are not, as they change and evolve according to the system of production. Therefore, labour rights are time-bound, less absolute, less morally compelling and, hence, not human rights. He still insists, however, on using a rights-based approach to labour litigation. $^{27}$

\section{The Nature of International Labour Law in Labour Codes of MNCs}

By promulgating labour codes, MNCs have effectively made themselves the global legislators of labour law. ${ }^{28}$ The codes represent the "private governance" of labour in the Global South, in stark contrast to and in competition with "public governance" by national labour law regimes. ${ }^{29}$ MNCs' most evident focus in their labour codes is workplace safety, primarily to avoid disasters and embarrassments such as the 2013 Rana Plaza factory collapse in Dhaka and the 2012 Ali Enterprises fire in Karachi, both of which shook Western consumers' consciousness. While it is true that safety conditions in Southern factories are often abysmal, MNCs' attempts to improve them frequently bypass national labour law regimes with "private auditing" or "hybrid governance" approaches to labour law like the Bangladesh Accord and the proposed Pakistan Accord. ${ }^{30}$ More than 200 foreign brands initiated two factory safety programmes under the Bangladesh Accord for Fire and Building Safety and the Alliance for Bangladesh Worker Safety. Demonstrating the limited scope of good intentions, however, they encompass only 27 percent of the factories in Bangladesh. ${ }^{31}$ National labour law regimes, in contrast, theoretically cover the entire country. Today, in Bangladesh, these labour codes bypass an already weak national labour law regime and cannot be said to strengthen it. ${ }^{32}$

Even after tragedies like Rana Plaza and Ali Enterprises, the ongoing, everyday structural exploitation of workers tends to remain hidden. Enforcing a minimum wage and providing social security are not directly linked to disasters, after all, and MNC labour codes usually only address structural exploitation issues with a checklist whose compliance is solely "assured" by social auditing firms. As revealed by the audit of the Ali Enterprises factory conducted by the social certifier RINA shortly before the 2012 fire, this type of auditing is easily corrupted or intercepted. Indeed, such social auditing processes are only cursory and partial by design. In the Rana Plaza tragedy, for example, the audit company Veritas asked the Canadian

\footnotetext{
${ }^{27}$ Collins (2011), p. 141.

${ }^{28}$ For the role of law in GVCs, see Santos (2016), pp. 36-39. See also Selwyn (2016), pp. 60-61.

${ }^{29}$ Milberg and Winkler (2013), p. 115.

${ }^{30}$ Becker (2015); Evans (2015), p. 597.

${ }^{31}$ Labowitz and Baumann-Pauly (2015), pp. 4-5.

${ }^{32}$ See Anner (2020), pp. 320-347.
} 
retailer Loblaws to pay an extra 2000 US dollars for the audit to cover the construction and structural integrity of the Rana Plaza building. Loblaws refused and, instead, requested that the manufacturer pay only 1200 US dollars for the basic social audit. Had the full audit been carried out, the evaluation of Rana Plaza's construction and structural integrity may have prevented the tragedy altogether. ${ }^{33} \mathrm{It}$ must also be pointed out that only mega-corporations can afford this form of selfauditing. Finally, even if companies take auditing seriously, like Nike, which invests 10 million US dollars in auditing processes annually and hires almost 100 employees to monitor the implementation of labour standards in labour codes across its global value chain, I argue that labour justice cannot be achieved by bypassing the state and workers. $^{34}$

\subsection{Avoiding Distributive Justice in Labour Codes}

Workers' safety and social security cannot be secured without assuring process rights, namely freedom of association and collective bargaining. According to Barbara J Fick, in a 1998 ILO study of 215 MNC labour codes, only 15 percent of them mentioned freedom of association and collective bargaining. Moreover, when the OECD published 246 MNC labour codes in 2001, only 60 percent mentioned core labour standards, and only 30 percent mentioned freedom of association. Similarly, out of 600 publicly-traded corporations' 2012 labour codes, only 43 percent mentioned freedom of association. ${ }^{35}$ Instead of being based on democraticallyelected, representative trades unions, the overall approach of labour codes authorised organising in "works councils," which are neither democratically elected nor designed for a power fight. ${ }^{36}$

Most of the "value added" is in "innovation" at the pre-production and postproduction stages of the GVCs. ${ }^{37}$ Manufacturing contractors of the South are assumed to add very little value despite the labourers' hard work at this stage of the production phase. At the same time, MNC labour codes transfer all labour responsibility and risk to manufacturing contractors in the Global South. In addition, the first-tier supplier gives third party contractors strict deadlines, which are passed down to labourers, often making them work overtime, in some cases even forcibly. Another dilemma is that profit redistribution is not recognised as a core value within MNC labour codes" "ethical" and "moral" intent. In interpreting these MNC codes in relation to the Rana Plaza disaster, courts in both Delaware in the United States and

\footnotetext{
${ }^{33}$ Doorey (2018), p. 12.

${ }^{34}$ As pointed out by Posthuma (2010), pp. 57-80.

${ }^{35}$ Fick (2014), p. 3.

${ }^{36}$ Engels-Zanden and Merk (2014), p. 466.

37 "Value added" here is the difference between production cost and the price of a product, which MNCs add at their discretion, see ILO (2016), p. 30.
} 
Ontario in Canada clearly concluded that they are mere moral and ethical statements, reaffirming that the codes have more cosmetic than preventive or corrective value. ${ }^{38}$ Redistribution (distributive justice), according to Guy Davidov, is one of labour law's main goals, but is usually neglected in labour law literature. In this chapter, I use the term, borrowing from Davidov, in the broader sense of theories of distributive justice. Based on the theories of John Rawls and Ronald Dworkin, distributive justice can be understood as the distribution of resources through labour law. In Amartya Sen's approach, according to Davidov, distribution is based on equality of capabilities rather than labour law's fight against oppression, caste and hierarchies in the workplace, based on the distribution of power and risk. ${ }^{39}$ With these understandings in mind, why do Southern workers and states not effectively resist the current turn away from labour law towards MNC labour codes? Dependent, investmentstarved countries tend to not only avoid all confrontation with MNCs, but they also act within MNCs' corporate hegemonic agenda of global capitalism. Critics, meanwhile, call out states" "outsourcing of governance" to MNCs and lament how they have effectively turned "labour law" into "labour self-regulation." "Self-regulation" means state interference in labour matters is reduced although MNCs can and often do ask investment-starved states to curb acts of labour dissent. In this context, workers are treated only as passive objects to be regulated by codes. ${ }^{41}$

Starting from the observation that few countries in the Global South currently have functional labour law regimes, some labour activists and analysts see MNC labour codes-especially contractually binding ones like the Bangladesh Accordas helpful in preventing already "bad" labour conditions from getting "worse." For example, Pakistan has only one percent unionisation. If MNC labour codes protect say 10 percent of workers or workplaces, these activists and analysts reason, that this is still 10 times more than before. This argument aligns with the "context" approach in international law literature, which sees violence as internal to countries in the Global South due to their lack of democracy and "good" governance. A critical approach to international law, however, takes colonial, neo-colonial and current neoliberal factors into account to explain local problems and challenges. ${ }^{42}$

\footnotetext{
${ }^{38} \mathrm{KiK}$ 's claim was that "codes of conduct" are only an ethical steering instrument. The court accepted that they are used to "maintain a certain minimum ethical, social, and labour standard," see KiK case at pp. 5, 10.

${ }^{39}$ For usefulness and relevance of all these theories, see Davidov (2018).

${ }^{40}$ Mayer and Phillips (2017), pp. 134-152; Arup et al. (2006).

${ }^{41}$ Engels-Zanden and Merk (2014), p. 465.

${ }^{42}$ Anghie and Chimni (2003), pp. 77-103.
} 


\subsection{Diluting “Labour Representation” in Labour Codes}

Critical labour law scholars like Karl Klare see redistribution as possible only through workplace democracy and participatory decision-making. ${ }^{43}$ Historically, this has paved the way for worker representation in the legislature, which, in turn, has enabled the creation of welfare states. ${ }^{44}$ In its simplest form, labour politics must involve worker representation at three progressive levels: in the workplace in the form of trade unions; in democratic state institutions and structures, such as parliament; and in international institutions. In this progression, labour representation at the workplace is a decisive indicator of representation at the national level, while both are prerequisites for active worker participation in institutions at the international level. If individual workers have low workplace representation and a negligible presence in the legislature, they can easily be ignored at the international level, whereas MNCs have a far easier time getting their voices heard. Claire Cutler points out, although the state is the subject of international law, MNCs have the power to influence transnational institutions like the EU, thus making them de facto members of such institutions. ${ }^{45}$

In many countries of the Global South, workers possess negligible representation in legislatures. Hence, when the US tried to add the topic of labour to the WTO agenda in the early 1990s, most member countries from the Global South strongly rejected attaching labour conditions to trade agreements. This was the main bone of contention in the two WTO ministerial conferences in Singapore (1996) and Seattle (1999). The EU and US have continuously pushed to include labour conditions in international trade agreements like the General Agreement on Tariffs and Trade (GATT) and, later, the WTO. Countries of the Global South have not only sought to avoid this, but have actively insisted that the ILO, not the WTO, be the chief forum for labour regulation. ${ }^{46}$ Historically, however, the US has ratified very few ILO labour conventions, not wanting itself to be bound by them. Instead, it has tried to push soft law labour standards through trade and investment treaties. In this regard, I see the rights-based approach to labour law currently accepted and promoted by the ILO as an indicator of the US approach's success.

Although Global South countries wanted the ILO to be the sole forum for labour regulation and sought to prevent arbitrary labour conditions from being used against them, ${ }^{47}$ we should not fool ourselves into believing that countries of the Global South were, therefore, in favour of strict labour law and distributive justice. A "global capitalist elite" has emerged in countries of the Global South that is not interested in the redistribution of wealth or worker safety. Instead, they aim to ensure global value chains and seek to keep the market running smoothly in order to

\footnotetext{
${ }^{43}$ Klare (1988), pp. 8-9.

${ }^{44}$ Klare (1988), p. 40.

${ }^{45}$ Cutler (2001), pp. $133-150$.

${ }^{46}$ For details of this controversy, see Stern and Terrell (2003); See also Howse (1999), p. 131.

${ }^{47}$ See Alston (2004), p. 457.
} 
safeguard their interests. According to BS Chimni, fractions of national capitalist classes have entered into coalitions with global production processes and emerged as the transnational capitalist class of the Third World. They are not junior to imperialist powers, but are independent players. $^{48}$

\subsection{Labour Codes as a Question of Power and Ideology}

Borrowing from John Ruggie, international institutions' approval of MNC labour codes is an indication of MNCs' significant structural power. ${ }^{49}$ Indeed, MNCs regularly exercise undue influence on international institutions. Global corporate spending on lobbying is 30 times that of unions and public interest litigation groups. In Brussels, where the EU is headquartered, businesses occupy 75 percent of all offices, while unions have less than five percent. ${ }^{50}$ Given this power imbalance, workers often have no real choice but to accept MNC labour codes. While this is clearly a form of economic coercion, ideology also plays an important role in the process. In this vein, academics are presenting MNCs' global value chains as a very complex form of economic organisation, with particularly complicated governance and management structures capable of defying human understanding. The fact that businesses work transnationally, whereas regulation only extends nationally is an argument often cited in this regard. Meanwhile, a great deal of academic literature examines the complexity of labour in global value chains with various contractors and subcontractors, ${ }^{51}$ where gender, ethnic and regional aspects add even more complexity. $^{52}$

This emphasis on complexity represents a process of global value chain reification. ${ }^{53}$ To elaborate this concept, Karl Marx gave the example of why the exchange value of diamonds is more than that of water, although water has far more use value than diamonds. According to Marx, the market determines the exchange value of commodities like diamonds, which completely abstracts it from their use value. Because this abstraction completely separates a commodity's exchange value from

\footnotetext{
${ }^{48}$ Chimni (2017), p. 37. For more on the Third World global capitalist class, see Harris (2009). For the transnational capitalist class, see Sklair (2000); see also Carrol (2010).

${ }^{49}$ Ruggie (2017), p. 7.

${ }^{50}$ Ruggie (2017), pp. 5-7.

${ }^{51}$ Chan (2013).

${ }^{52}$ Barrientos (2014), p. 791. Mezzadri and Lula (2018), pp. 1034-1036. Mezzadri (2016), pp. 1877-1900. Werner and Bair (2011), p. 988. Carr and Chen (2004), p. 129.

${ }^{53}$ Reification is the transforming of social relations/properties/actions into relations/properties/ actions of human-made things. Through this process, human-being starts looking thing-like and the laws of human ways become the laws of things. In short, we start talking about social relations of producers as relations of products of labour. That is, I am a labourer and he is an intellectual and we are not human beings. Once this process is completed, commodity relations start looking like normal social relations. See Brosnan (1986-87), p. 279.
} 
its material properties, only its supra-natural properties can explain its value. ${ }^{54}$ Hence, the supra-natural presentation of global value chains as complex and MNC labour codes as benevolent for workers both contribute to this process of reification. In this sense, the very idea of CSR also has a role to play in that it presents corporations as good citizens.

MNC labour codes are given tremendous legitimacy by international institutions like the ILO and OECD, as well as other stakeholders like labour NGOs that participate in stakeholder initiatives and negotiations. ${ }^{55}$ These legitimacy processes and discursive practices allow very mild responses to MNC labour code violations, such as merely asking for them to be binding contracts.

\section{Private Law in Labour Litigation}

Legal scholars and practitioners are divided on the use of private law doctrines in labour law violation cases. Since MNC labour codes tend to have a strong moral and ethical grounding, many suggest using tort and contract law to combat violations in global value chains. ${ }^{56}$ However, the results of this type of litigation show the limits of this approach, and many writers increasingly suggest the need to go beyond the use of private law and labour codes. ${ }^{57}$

In the US, legal practitioners have often used the 1789 Alien Tort Claims Act (ATCA) against MNCs. Under this act, non-state actors can bring tort claims against US companies for violating the "law of nations." 58 Despite the somewhat encouraging case of Sosa v. Alverez-Machin, ${ }^{59}$ however, this approach's utility for labour struggles has been limited in that US circuit courts have rarely entertained cases about sweatshop conditions. To date, they have only taken on sensational labourrelated cases, such as those involving union leaders' murder, torture and rape, or those involving the slave trade. Apart from a successful 2004 case against Nike, ${ }^{60}$ US courts have generally failed to address cases involving structurally poor labour

\footnotetext{
${ }^{54}$ Marx (1976), pp. 128, 149 as cited by McNally (2015), pp. 131-146.

${ }^{55}$ These are called "labour movement-oriented NGOs," which are different from "social serviceoriented NGOs" or "legal rights-oriented NGOs." See Chan (2018), pp. 1-18. Chan (2012), pp. 308-327.

${ }^{56}$ For the overall return to private law, see Goldberg (2012); see also Smith (2017).

${ }^{57}$ Revak (2012), p. 1645.

${ }^{58}$ See for example, Aldana v. Del Monte Fresh Produce N. A., Inc., 416 F. 3r 1242 (11th Cir, 2005), see also Jane Does I v. Wal-Mart Stores Inc., No.CV05-7307 AG (MANx, 2007) WL 5975664 (C. D. Cal. Mar. 30, 2007), also Does I v. Gap. Inc. No. CV-01-0031, 2002 WL 1000068 (D. N. Mar. J May 10, 2002).

${ }^{59} 542$ US 692, 2004.

${ }^{60}$ See CCC (2004); Bas (2004).
} 
conditions. $^{61}$ A 2007 case against Wal-Mart ${ }^{62}$ was particularly disappointing for proponents of using private law for labour cases. In this case, lawyers invoked a third-party beneficiary breach of contract against the company for standard violations, unjust enrichment and profiting from factory sweatshop labour in China, Bangladesh, Indonesia and other countries. However, the US Court of Appeals for the Ninth Circuit rejected the claim on the grounds that the contractor's obligation to comply with labour codes was split between the contractor and Wal-Mart, not between Wal-Mart and factory workers. ${ }^{63}$

The attempt to provide workers with redress by expanding private law's scope is laudable. But according to statistics compiled by John Ruggie, out of 150 cases that have used the US Foreign Corrupt Practices Act and ATCA since 1997, only one case reached a jury, and the corporation won that case. ${ }^{64}$ In two cases, the aggrieved party received modest settlements, while the remaining cases were all dismissed on various procedural grounds. ${ }^{65}$ Today, conventional labour law seems to offer no remedy for labour violations in global production contexts, requiring activists to use private law to address labour grievances.

\section{A Critical Reflection on the KiK and Ali Enterprises Cases}

For workers in Global South countries with low social security protection and weak organised labour, the core values of labour law are redistribution and worker representation. This final section explores how labour activists and lawyers tried to use these values in litigating the KiK case in Dortmund, Germany, and the Ali Enterprises case in Pakistan. It concludes with some lessons for future litigation.

In the KiK case, lawyers and activists were very conscious about the limits of law and litigation. They were also clear that acts of solidarity and labour organising have the ability to be far more effective than resorting to the courts for justice. The KiK case was not (only) about winning a legal claim. ${ }^{66}$ Instead, the general position of the lawyers and activists involved in the case was that "legal interventions like the lawsuit against $\mathrm{KiK}$ in Germany open a small space to imagine and to eventually claim a different economic, social and legal world order." ${ }^{\text {, } 7}$ This is also evident in

\footnotetext{
${ }^{61}$ Maryanov (2010), p. 401.

${ }^{62}$ Jane Does I v. Wal-Mart Stores, Inc. No. CV 05-7307 AG (MANx), 2007 WL5975664; see also Does v. Wal-Mart Stores, US Court of Appeals 9th Circuit, 572 F. 3d 677 (2009).

${ }^{63}$ Jane Does I v. Wal-Mart Stores, Inc. No. CV 05-7307 AG (MANx), 2007 WL5975664; see also Does v. Wal-Mart Stores, US Court of Appeals 9th Circuit, 572 F. 3d 677 (2009).

${ }^{64}$ Ruggie (2017), p. 4.

${ }^{65}$ Ruggie (2017), p. 4.

${ }^{66}$ Bader et al. (2019), p. 167.

${ }^{67}$ Bader et al. (2019), p. 169.
} 
their overall appraisal of the litigation's obstacles, strategies and achievements. ${ }^{68}$ Yet, what is this "small space" that we can imagine? It is a space that lies beyond the current problematic dominance of the market economy and neoliberalism's theoretical underpinnings in international institutions' hegemonic agenda.

If we look at the redistributional aspect of labour law in the $\mathrm{KiK}$ case, workers received compensation, which was neither meant to be a substitute for human life nor about redistributing corporate profits. As Faisal Siddiqi, the main lawyer representing workers in the Ali Enterprises case, assessed the situation, using local labour courts would have led to very meagre compensation (see also chapter "Paradoxes of Strategic Labour Rights Litigation: Insights from the Baldia Factory Fire Litigation”). While this assessment was perhaps accurate, Siddiqi himself later came to regret the strong legal emphasis on compensation in the strategy devised by his legal team and collaborating activists, because it led them to overlook the potential benefits of long-term statutory and constitutional interventions, such as amending worker compensation and safety laws, among others. ${ }^{69}$ In the end, however, the $\mathrm{KiK}$ case litigation and the overall pressure it helped generate from the EU around Pakistan's GSP+ status, did result in certain legislative advances for worker safety and domestic and home-based workers, even bringing agricultural labour within the ambit of formal labour law. ${ }^{70}$

Did the KiK case help in the enhancement of workers' representation? To expect that it could have occurred from mere legal strategy is certainly wrong, particularly due to the restrictive nature of civil law and civil procedure for advancing broader community concerns. Part of the strategy adopted in the KiK case was that four of those affected (workers, survivors, family members) would challenge the company in a foreign court, since the company is untouchable in Pakistan, and use the opportunity to speak out on behalf of the whole group of victims. This strategy sought to use the law's paradoxes for limited aims in the absence of (functional/ effective) transnational labour law.

Let us critically analyse the Ali Enterprises and KiK cases whilst presupposing that labour law is a tool for gaining labour power. In the Ali Enterprises case, activists diligently used power gaps in elite institutional structures. Rejecting the old Marxist position of law as an instrument of the local elite, Faisal Siddiqui and several labour activists used the "anarchy of law" in local courts to seek relief for workers by co-opting (the instrumentality of) law from the local elite. ${ }^{71}$ This position sides with theories about law's relative autonomy, which hold that law is neutral and autonomous from social classes. Notably, law's instrumentality and relative autonomy are

\footnotetext{
${ }^{68}$ See for example Wesche and Saage-Maßß (2016), pp. 370-385; see also Terwindt et al. (2017).

${ }^{69}$ See chapter "Paradoxes of Strategic Labour Rights Litigation: Insights from the Baldia Factory Fire Litigation" by Siddiqi in this book.

${ }^{70}$ For example Sindh Occupational Safety and Health Act, 2017 and Punjab Occupational Health and Safety Act, 2019; see also chapter "Paradoxes of Strategic Labour Rights Litigation: Insights from the Baldia Factory Fire Litigation" by Siddiqi in this book.

${ }^{71}$ See chapter "Paradoxes of Strategic Labour Rights Litigation: Insights from the Baldia Factory Fire Litigation" by Siddiqi in this book.
} 
not inherent characteristics of law. They come from the organised power of the working class or the community, be it the momentary consolidation of forces of a dominated class (leading to seemingly random and anarchic gains), as happened in the Ali Enterprises case, or durable and balanced power-sharing between classes (leading to social democratic legislation and its implementation through the courts). This shows that political struggles have primacy over legal struggles.

According to the critical approach of Peter Gabel and Paul Harris in the US context, US lower courts should be used as a real powerbase for alternatives and higher courts, especially the supreme court, should be used to shake up and challenge ideology. ${ }^{72}$ Using this corollary to evaluate transnational litigation against MNCs, from the analysis so far, it seems that the case against KiK was more ideologically oriented. It explored the possibility of emancipation for labour through the labour codes of MNCs and the use of private law for labour litigation. The Ali Enterprises case on the other hand had a legal-power orientation as it used local power gaps and organised labour. Yet, we cannot separate the concrete expression of power (organised labour) from the power of ideology or the rights-based approach to labour law and its use of private law. Borrowing from Gabel and Harris and other critical scholars, outcomes of a case are not the only important factor. Rather it is further the very categories in which a dispute is defined. ${ }^{73}$ According to Gabel and Harris, the law convinces us to accept hierarchy and pacifies conflict. Law channels social and economic conflicts into heavily-laden rituals and authoritarian symbolism. The law imagines a community with rights and under the "rule of law," whereas the real community seems to have neither. In this way, law receives "democratic consent" for an inhuman social order, which runs counter to real democratic participation. ${ }^{74}$ A non-alienated consciousness and the empowerment of labour cannot be assured through a rights-based approach. Unless we engage in litigation critically, law disempowers workers rather than lifting them up.

Furthermore, a rights-based approach in litigation assumes that power resides with the state and corporations. However, power is an interdependent concept that can also be attributed to people who are organised. For example, critical legal scholars argue that strengthening tenant rights does little to challenge existing landlordism and actually accepts the inequality of land distribution. Similarly, collective bargaining accepts the hierarchy of prevailing labour relations, as well as the basic division of people into labour and capital. ${ }^{75}$ Meanwhile, race and gender sensitive activists who have at times successfully used the courts and liberal rights to challenge racial and gender discrimination and subjugation, ${ }^{76}$ strongly critique some of the more nihilistic strands in critical legal studies.

\footnotetext{
${ }^{72}$ See Gabel and Harris (1982).

${ }^{73}$ Gabel and Harris (1982), pp. 375-376.

${ }^{74}$ Gabel and Harris (1982), p. 372.

${ }^{75}$ Gabel and Harris (1982), p. 373.

${ }^{76}$ For a strong rebuttal by gender and race activists, see Williams (1987), pp. 401-434; Crenshaw (1988), pp. 1331-1387; Scales-Trent (1989), pp. 9-44; Schneider (1986), pp. 589-652.
} 
Apart from this debate on rights in the critical legal tradition ${ }^{77}$ and its rebuttal, we cannot escape courts and the law. We therefore need to build our critical practices on practical and theoretical insights into "critical lawyering," "collaborative lawyering" and "third-dimension lawyering." 78 The focus of this type of lawyering is on empowering communities and changing client-lawyer relationships by asking lawyers to be humble and reflective. ${ }^{79}$ It is pertinent to mention here that NGO rhetoric including terms like "community," "empowerment," "social change," "grassroots" and "self-initiative" can be slippery and disempowering. ${ }^{80}$ Therefore, it is important that critical lawyers and NGOs have a critical consciousness; they must see the poor as a historical class, not as atomised individuals; they must perceive class as an active human relationship in everyday life connected to a culture of domination and liberation. This consciousness should be the core of service litigation for individual clients, reform litigation to change institutional policies and practices, and even in remedial litigation in the field of the welfare state. ${ }^{81}$

The rights-based approach to labour law is channelled to Pakistan through labour NGOs, social movements and, now, through the "hybrid governance" of labour codes in global value chains like the Pakistan Accord. ${ }^{82}$ "Rights" in social democracies with welfare states, where the working class has acquired reasonable political representation, mean a very different thing than "rights" in a dismantled environment like Pakistan. When Karl Klare critiqued the liberal market logic of collective bargaining in the US, he had the European welfare state in mind. ${ }^{83}$ But labour in countries of the Global South is generally not allowed to organise and there are deliberate attempts under neoliberalism to roll back unions' meagre achievements. In this scenario, the rights-based approach, with its discursive power and inherent hegemonic liberal underpinnings, dilutes the institutional power arrangements that facilitate freedom of association and collective bargaining. The labour demand for workplace representation is not only important for redistribution, but also to address the dire lack of political representation in most Global South democracies.

To conclude, the values of redistribution and representation must remain central to labour struggles and labour law. MNCs' labour codes, rights-based approaches, and private law should not be and cannot be a substitute for the radical democratic tradition of labour law with its emphasis on guaranteeing workers' freedom of association and collective bargaining. Above all, legal strategies and labour law should be seen as questions of labour politics and labour power.

\footnotetext{
${ }^{77}$ For rights related to labour issues, see: Klare (1981), p. 157; for a general critique of the rightsbased approach, see Chase (1984), p. 1541; Gable and Harris (1982), p. 1563.

${ }^{78}$ See for example Alfieri (1991), p. 2107; Alfieri (1988), p. 659; Lopez (2005), p. 2041; White (1994), p. 157.

${ }^{79}$ White (1995), p. 158.

${ }^{80}$ White (1995), pp. 169-170.

${ }^{81}$ Alfieri (1988), pp. 663-665.

${ }^{82}$ Mayer and Phillips (2017), pp. 134-152.

${ }^{83}$ Klare (1988), pp. 8-9.
} 


\section{References}

Alfieri AV (1988) The antinomies of poverty law and a theory of dialogic empowerment. N Y Univ Rev Law Soc Change 16:663-665

Alfieri AV (1991) Reconstructive poverty law practice: learning lessons of client narrative. Yale Law J 100:2107

Alston P (2004) Core labour rights: the story. EJIL 15:457

Anghie A, Chimni BS (2003) Third World approaches to international law and individual responsibility in internal conflicts. Chin J Int Law 2:77-103

Anner M (2020) Squeezing workers' rights in global supply chains: purchasing practices in the Bangladesh garment export sector in comparative perspective. Rev Int Polit Econ 27 (2):320-347

Arup C, Gaham P, Howe J, Johnstone R, Mitchell R, O’Donnel A (2006) Labour law and labour market regulation: essays on the construction, constitution and regulation of labour markets and work relationships. Federation Press, Sydney

Bader M, Saage-Maaß M, Terwindt C (2019) Strategic litigation against the misconduct of multinational enterprises: an anatomy of Jabir and Others $v$ Kik. Verfassung und Recht in Übersee 52:156-171

Barrientos S (2014) Gendered global production networks: analysis of cocoa-chocolate sourcing. Reg Stud 48:791

Bas FN, Benjamin M, Chang CJ (2004) Saipan sweatshop lawsuit ends with important gains for workers and lessons for activists. Business and Human Rights Resource Centre

Becker L (2015) Are supply chains transnational legal order? What we can learn from the Rana Plaza factory building collapse. UC Irvine J Int Transnatl Comp Law 11

Bercusson B, Estlund C (2006) Regulating labour in the wake of globalisation, 1st edn. Hart Publishing

Bogg A (2017) Labour, love and futility: philosophical perspective on labour law. Int J Comp Labour Law Ind Relat 3:7-37

Brosnan FD (1986-87) Serious but not critical. South Calif Law Rev 60:279

Carrol WK (2010) The making of transnational capitalist class: corporate power. In: The 21st century. Zed Books

Carr M, Chen M (2004) Globalization, social exclusion and gender. Int Labour Rev 143:129

Chan CK-C (2012) China class or citizenship? debating workplace conflict in China. J Contemp Asia 42:308

Chan MK (2013) Contract labor in global garment supply chains: key characteristics and recent trends. Women in informal employment: globalizing and organizing. WIEGO, Manchester

Chan A (2018) The Relationship between labor ngos and chinese workers in an authoritarian regime. Global L J 9:1

Chase A (1984) A challenge to workers rights. Nova Law Rev 8:671

Chimni BS (2017) Anti-imperialism: then and now. In: Nesiah V et al (eds) Bandung, global history and international law: critical pasts and pending futures. Cambridge University Press, Cambridge

Collins H (2011) Theories of rights as justifications for human rights. In: Davidov G, Langille B (eds) The idea of labour law. Oxford University Press, Oxford, p 140

Conaghan J (2005) Work, family, and the discipline of labour law. In: Conaghan J, Rittich K (eds) Labour law, work and family. OUP

Coutu M (2013) With Hugo Sinzheimer and Max Weber in mind: the current crisis and future of labour law. Comp Labor Law Policy J 34:607-608

Crenshaw KW (1988) Race, reform, and retrenchment: transformation and legitimation in antidiscrimination law. Harv Law Rev 101(7):1331-1387 
Cutler A (2001) Critical reflections on the Westphalian assumptions of international law and organization: a crisis of legitimacy. Rev Int Stud 27(2):133-150

Davidov G (2018) Distributive Justice and Labour Law. In: Collins H, Lester G, Mantouvalou V (eds) Philosophical foundations of labour law, OUP

Doorey DJ (2018) Lost in translation: Rana Plaza, Loblaws, and the disconnect between legal formality and corporate social responsibility

Duke R (2008) Constitutionalizing employment relations: Sinzheimer, Kahn-Freund, and the role of labour law. J Law Soc 35(3):341-363

Dukes R (2009) Otto Kahn-Freund and collective laissez-faire: an edifice without a keystone? Mod Law Rev 72(2):219-246

Engels-Zanden N, Merk J (2014) Private regulation and trade union rights: why codes of conduct have limited impact on trade union rights. J Bus Ethics 123(3):123-466

Evans BA (2015) Accord on Fire and Building Safety in Bangladesh: an international response to Bangladesh labour conditions. N C J Int Law 40(2):597

Ewing K (1988) The death of labour law? Oxford J Leg Stud 8:293

Fick B (2014) Corporate social responsibility for enforcement of labour rights: are there more effective alternatives?

Fudge J (2007) The new discourse of labour rights: from social to fundamental rights. Comp Labour Law Policy J 29(1):29-66

Gabel P, Harris P (1982) Building power and breaking images: critical legal theory and the practice of law. N Y U Rev L \& Soc Change 11:372

Goldberg JCP (2012) Introduction: pragmatism and private law. Harv Law Rev 125:1640

Harris J (2009) Statist globalization in China, Russia and the Gulf States. Science \& Society 73:6

Howse R (1999) The world trade organization and the protection of workers rights. J Small Emerg Bus Law 3:131

ILO (2016) Report IV, Decent work in global supply chains

Kahn-Freund O (1970) Trade unions, the law and society. Mod Law Rev 33(3):241-267

Klare KE (1981) Labor law as ideology: toward a new historiography of collective bargaining law. Indus Rel L J 4:450

Klare K (1988) Workplace democracy and market reconstruction: an agenda for legal reform. Cathol Univ Law Rev 38(1):1-68

Labowitz S, Baumann-Pauly D (2015) Beyond the tip of the iceberg: Bangladesh's forgotten apparel workers. NYU Stern Centre for Business and Human Rights, New York, pp 4-5

Langille B (2005) Core labour rights - the true story. Eur J Int Law 16(3):409-437

Lewis R (1979) Collective agreements: the Kahn-Freund legacy. Mod Law Rev 42:613-622

Lopez GP (2005) Living and lawyering rebelliously. Fordham L Rev 73:2041

Maryanov DC (2010) Sweatshop liability: corporate codes of conduct and the governance of labour standards in the international supply chains. Lewis Clark Law Rev 14:401

Mayer FW, Phillips N (2017) Outsourcing governance: states and the politics of a "global value chain world". New Polit Econ 22(2):134-152

McCarthy B (1964) The closed shops in Britain as cited by Undy R. An overview of Bill McCarthy's academic and political engagement with industrial relations. Ind Relat J 46:1-6

McNally D (2015) The dialectics of unity and difference in the constitution of wage-labor: on internal relations and working-class formation. Cap Class 39(1):131-146

Mezzadri A (2016) Class, gender, and the sweatshop: on the nexus between labour commodification and exploitation. Third World Q 10:1877

Mezzadri A, Lula F (2018) "Classes of labor" at the margins of global commodity chains in India and China. The Institute of Social Studies, pp 1034-1036

Milberg W, Winkler D (2013) Outsourcing economics: global value chains in capitalist development. Cambridge University Press, New York, p 115 
Mumme C (2019) Rights, freedoms, law, labour and industrial voluntarism: some comments

Posthuma A (2010) Beyond 'Regulatory enclaves': challenges and opportunities to promote decent work in global production networks. In: Posthuma A, Nathan D (eds) Labour in global production networks in India. OUP

Revak H (2012) Corporate codes of conduct: binding contract or ideal publicity? Hastings Law J 63:1645-1670

Ruggie JG (2017) Multinationals as global institutions: power, authority and relative autonomy. Regul Gov:1-17

Santos BD (2002) Towards a new common sense: law, science, and politics in the paradigmatic transition, $\mathrm{p} 483$

Santos A (2016) The role of law in global value chains: a research manifesto. Lond Rev Int Law 4 (1):36-39

Scales-Trent J (1989) Black women and the constitution: finding our place, asserting our rights. Harv Civ Rights-Civ Liberties Law Rev 9:9-44

Schneider EM (1986) The dialectic of rights and politics: perspectives from the women's movement. N Y Univ Law Rev 61:589-652

Selwyn B (2016) The role of law in global value chains: a research manifesto. Lond Rev Int Law 4 (1):60-61

Sklair L (2000) The transnational capitalist class. Camb Rev Int Aff 14:67

Smith JM (2017) Enforcing corporate social responsibility codes under private law: on the disciplining power of legal doctrine. Ind J Global Legal Stud 24:99

Stern RM, Terrell K (2003) Labor standards and the world trade organization. Research seminar in international economics, Ann Arbor

Terwindt C, Leader S, Yilmaz-Vastardis A, Wright J (2017) Supply chain liability: pushing the boundaries of the common law. J Eur Tort Law 8:261

Wedderburn L (1987) Labour law: from here to autonomy. Indus Law J 16(1):1-29

Werner M, Bair J (2011) Commodity chains and the uneven geographies of global capitalism: a disarticulations perspective. Environ Plan 43:988

Wesche P, Saage-Maaß M (2016) Holding companies liable for human rights abuses related to foreign subsidiaries and suppliers before German civil courts: lessons from jabir and others $\mathrm{v}$ kik. Hum Rights Law Rev 16:370

White LE (1994) Collaborative lawyering in the field - on mapping the paths from rhetoric to practice. Clinical L Rev 1:157

White LE (1995) Collaborative lawyering in the field - on mapping the paths from rhetoric to practice. Clin Law Rev 1:158-170

Williams JP (1987) Alchemical notes: reconstructing ideals from deconstructed rights. Harv Civ Rights-Civ Liberties Law Rev 22:401-434

Muhammad Azeem is assistant professor at Shaikh Ahmad Hassan School of Law at Lahore University of Management Sciences in Lahore, Pakistan, where he teaches labour law, critical legal theory, as well as international law from a Southern, decolonialist perspective. He has published widely in Urdu and English, most recently on labour conditions in global value chains and the China-Pakistan Economic Corridor. After practicing law and pursuing public interest litigation around issues concerning workers and peasants in Pakistan's lower and high courts for several years, he obtained a Master of Laws and Doctor of Philosophy from Osgoode Hall Law School in Toronto, Canada. Azeem is a labour organiser and an active member of the Progressive Writers Association of Lahore. He also writes poetry and criticism in Urdu and Punjabi. 
Open Access This chapter is licensed under the terms of the Creative Commons Attribution 4.0 International License (http://creativecommons.org/licenses/by/4.0/), which permits use, sharing, adaptation, distribution and reproduction in any medium or format, as long as you give appropriate credit to the original author(s) and the source, provide a link to the Creative Commons license and indicate if changes were made.

The images or other third party material in this chapter are included in the chapter's Creative Commons license, unless indicated otherwise in a credit line to the material. If material is not included in the chapter's Creative Commons license and your intended use is not permitted by statutory regulation or exceeds the permitted use, you will need to obtain permission directly from the copyright holder. 